УДК 621.396 .4

Т. О. Прищепа

\title{
ВПЛИВ МОБІЛЬНОСТІ НА ПРОДУКТИВНІСТЬ БЕЗПРОВОДОВИХ СЕНСОРНИХ МЕРЕЖ
}

Анотація. В статті розглянуто еволюція мобільних безпроводових сенсорних мереж та характеристики іiі мережевої архітектури, що відрізняють іiі від статичних безпроводових сенсорних мереж. Наведено аналіз впливу мобільності на показники продуктивності роботи безпроводової сенсорної мережі.

Ключові слова: мобільна безпроводова сенсорна мережа, безпроводова сенсорна мережа, мобільність.

\section{Вступ}

Концепція мобільних безпроводових сенсорних мереж у контексті всеосяжних обчислювальних мереж зародилась недавно, хоча дослідник лабораторії Xerox PARC Марк Вейзер передбачив її ще у 1991 році. Наряду з еволюцією БСМ з'явилось нове поняття присутності мобільних приймачів інформації або агентів. Зараз мобільність у БСМ є перевагою, а не проблемою. Результати [1-4] показують, що мобільність не тільки підвищує час функціонування мережі, а й дозволяє вирішити питання затримки при передачі. Більшість характеристик МБСМ такі самі, як у БСМ, але:

- Через мобільність МБСМ мають більш динамічну топологію, ніж статичні БСМ. Передбачається, що приймач інформації буде випадково і неперервно пересуватись, надаючи мережі дуже динамічну топологію. Це впливає на такі аспекти, як вибір протоколу маршрутизації, протоколу канального рівня та фізичної апаратури.

- У більшості випадків можна припустити що приймач інформації має нескінченні запаси енергії та обчислювальних ресурсів. Вичерпані батареї мобільних приймачів інформації можуть бути заряджені або замінені, та на них можна розмістити великі обчислювальні пристрої та пристрої накопичення даних.

- Через підвищену мобільність МБСМ накладаються обмеження на вже запропоновані протоколи маршрутизації та канального рівня. Більшість ефективних протоколів з БСМ мають низьку ефективність у МБСМ.

- Через динамічну топологію МБСМ канали зв'язку мають низьку надійність. Це особливо проявляється у віддалених зонах, де створення постійного каналу зв'язку з мінімальним QoS є проблемним.

- Через мобільність важливу роль починає відігравати оцінка місцеположення, для виявлення розміщення сенсора чи приймача інформації.

Вважається, що МБСМ мають більш продуктивні канали, ніж статичні БСМ. Приріст продуктивності мережі з мобільним приймачем інформації у 3-5 разів більша,

(C) Т. О. Прищепа 
ніж у статичних БСМ, якщо кількість приймачів інформації зростає пропорційно до кількості сенсорів[5]. Іншою перевагою МБСМ є краще наведення. Оскільки більшість сенсорів розгортається випадково, а не точно, часто виникає необхідність перемістити сенсор для кращого вимірювання. Крім того мобільність дозволяє підняти якість даних. Загальновідомо, що ймовірність помилки зростає 3 кількістю проміжних вузлів, через які проходять дані. Якщо зменшити кількість проміжних вузлів, це зменшить ймовірність помилки. Це не лише збільшує якість даних, але й зменшує кількість енергії, що витрачається на повторну передачу даних з помилками.

\section{1. Еволюція МБСМ та характеристики їі мережевої архітектури, що відрізняють її від БСМ}

Мобільні безпроводові сенсорні мережі одержали свою назву завдяки наявності мобільного одержувача інформації або мобільних сенсорних вузлів в мережі.

При застосуванні мобільного одержувача інформації можливо досягти нижчого та більш збалансованого споживання енергії у БСМ завдяки наступним особливостям:

- Односкачкова кластеризація. При використанні виключно прямої передачі даних між скачками, всі сенсорні вузли багаторівневої передачі стають зайвими. Сенсорні вузли одержують можливість входження в режим сну до моменту наближення одержувача інформації. Це дозволяє заощадити енергетикний бюджет, що був виділений на багаторівневу передачу.

- Мобільність і координація одержувача. Для застосування БСМ, ще не $\epsilon$ критичними до затримок, один мобільний вузол збору даних виконує функції багатьох статичних вузлів, що розміщені в різних позиціях. Оскільки наявність багатьох вузлів збору даних призводить до більш однорідного розподілу споживання енергії, зменшується ймовірність виникнення "енергетичної діри", та покращується покриття мережі.

- Позиціонування та ідентифікація із залученням мобільності. Сенсорні вузли можуть оцінювати свою позицію на основі інформації про мобільність одержувача інформації, що може періодично транслюватись. Якщо кожен сенсор буде географічно локалізований, стає можливим використання цієї інформації для більш ефективної маршрутизації інформації.

- Покращене масштабування мережі через зменшення навантаження протоколів канального та мережевого рівня на обмежені у ресурсах сенсорні вузли, що с особливо важливим у мережах з високою щільністю розміщення вузлів. При цьому зменшується складність підтримки мережевих функцій, особливо управління топологією та зв'язком.

- Адаптивна конфігурація мережі. Ця характеристика досягається завдяки реорганізації мережі та проведенню спостережень за динамікою вимірюваних показників середовища на різних масштабах простору та часу. 
Але на фоні позитивних змін застосування мобільного одержувача інформації може привести до такого недоліку як затримка доставки повідомлення: цей недолік пов'язаний зі зростанням затримки на установлення каналу зв'язку з вузлом збору даних. Для усунення втрат продуктивності можна збільшувати кількість вузлів збору даних у мережі та раціонально планувати траєкторію мобільних збирачів даних.

На відміну підходів, що застосовуються у "плоских" мережах, мобільні сенсорні мережі з мобільним доступом (МБСМ) дозволяє здійснювати дозволяють здійснювати як дистанційне, так і локальне зондування мобільними телефонами для виділення інформації про навколишнє середовище. Ця система є багаторівневою, що можна побачити на рис. 1: рівень сенсорів, рівень мобільних приймачів, рівень базових станцій (БС). На рівні сенсорів утворюється кластер із сенсорних вузлів, додаткових міток та мобільних приймачів у якості ядер кластеру. На рівні мобільних приймачів здійснюється локальна або віддалена координація для усунення надлишковості, що здійснюється через радіосистеми далекої та короткої дії, що є наявні на мобільних телефонах. На рівні базових станцій зібрана сенсорна інформація зберігається і перенаправляється у Internet через базові станції мобільної мережі, що служать точками доступу мережі Internet.

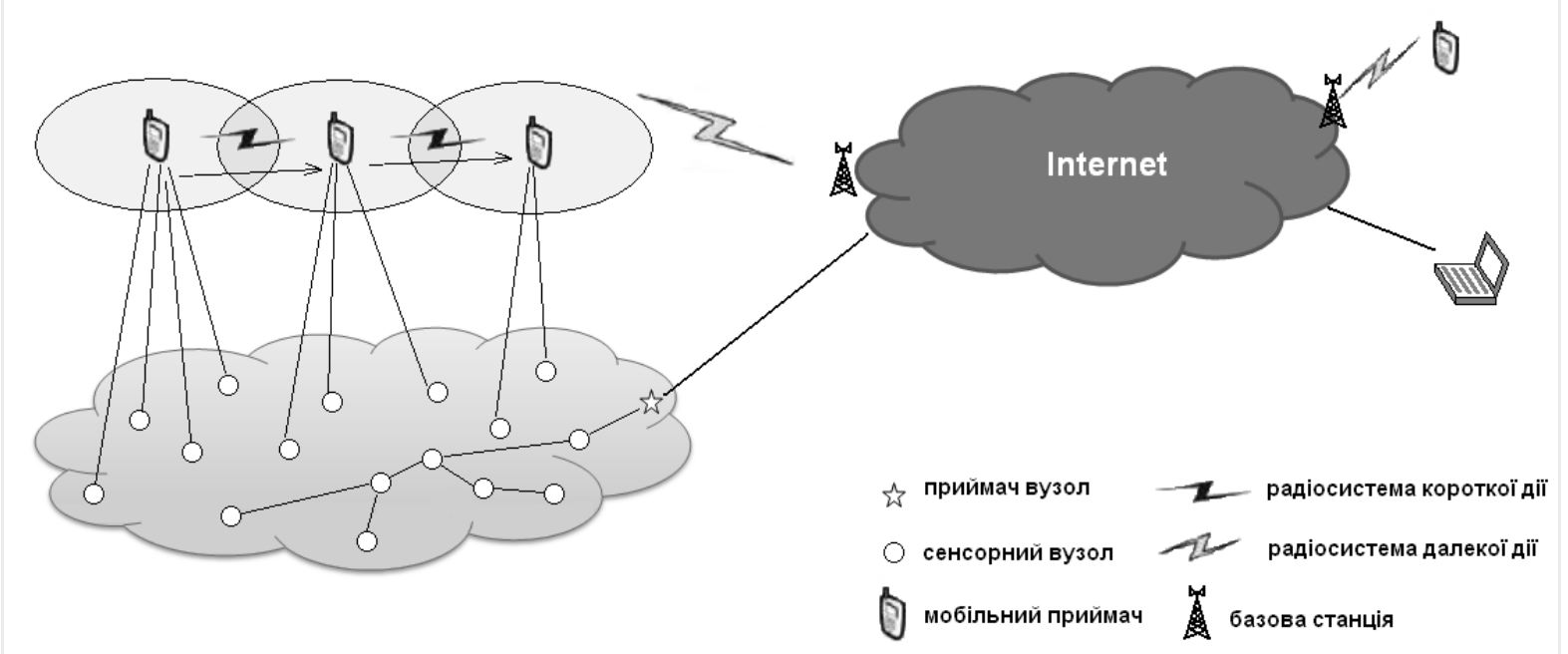

Рис. 1. - Архітектура безпроводової сенсорної мережі із мобільним доступом (МБСМ)

МБСМ працюють у одному з двох режимів: режимі локального вимірювання або режимі дистанційного вимірювання. У випадку локального зондування (рис. 2 a), після одержання запиту від мобільного приймача інформації, сенсорна інформація відправляється із статичних вузлів до мобільного приймача, що перенаправляє іï до БС для виконання обробки, що включає розбір та трансляцію у інше представлення. У випадку дистанційного зондування (рис. 2 б) мобільний приймач надсилає запит до БС, що призначає завдання зондування іншому 
приймачу, або одержує інформацію з бази даних в мережі Internet. Різниця між локальним та дистанційним зондуванням полягає у розміщенні мобільного приймача та сенсорів: якщо розміщення сенсорів та приймача не співпадає, то це віддалене зондування; інакше це локальне зондування.

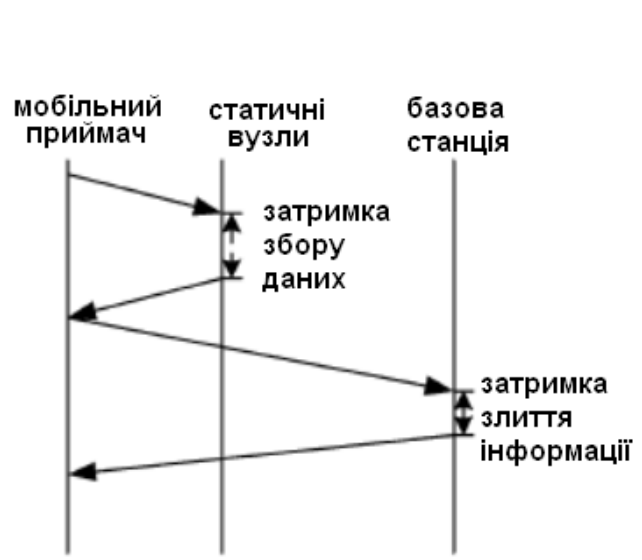

$a$

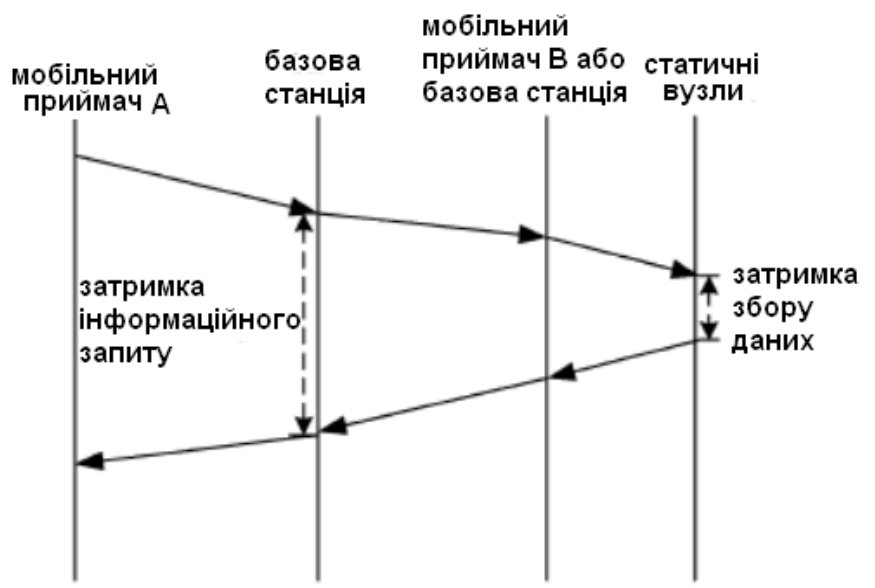

$\sigma$

Рис. 2. - Локальне та дистанційне зондування у МБСМ

Існують два види МБСМ за видом каналів зв’язку. Мережа з інфраструктурою має мобільного вузла, що безпосередньо під’єднаний до найближчої БС у своєму радіусі дії, як у сучасних мобільних телефонних мережах. Безінфраструктурна, або ad-hoc, мережа не має фіксованих маршрутизаторів, а всі мобільні вузли можуть пересуватись довільним чином з самоорганізацією та установленням довільних зв’язків.

\section{2. Вплив мобільності на продуктивність роботи центральних вузлів у односкачкових МБСМ.}

Існуючі підходи, що використовують мобільність центральних вузлів (стоків), можуть бути класифіковані відповідно до властивостей мобільності вузлів, особливостей передачі даних, маршрутизації та кількості мобільних стоків. 3 точки зору наявних даних про мобільність стоків можна виділити три типи мобільності вузлів: випадкова, передбачувана та контрольована. У відношенні кількості ланок передачі (скачків) між сенсором та стоком є два основні варіанти: односкачкова схема та багатоскачкова (рис. 3).
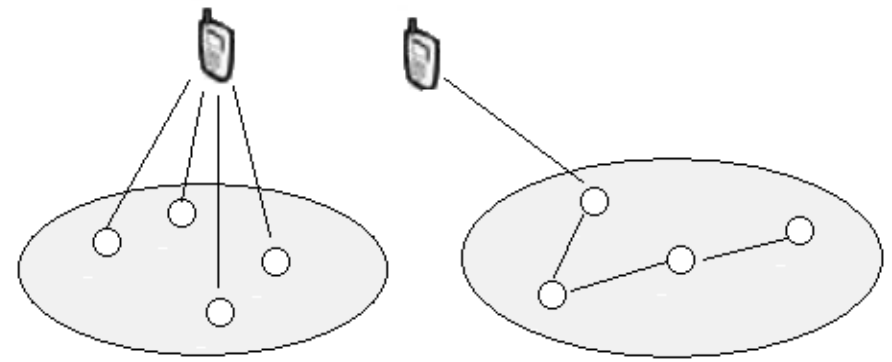

Рис. 3. - Односкачкова та багатоскачкова схеми 
Кількість скачків між сенсором та стоком також визначає радіус кластера у кластеризованих БСМ. Більшість наукових праць у цьому напрямку розглядає мобільність єдиного стоку. Проте, якщо можлива координація між багатьма стоками, може бути виконана загальна оптимізація.

Як відомо, традиційне визначення для БСМ описує гомогенну мережу з однорівневою архітектурою, де всі вузли крім стоку та шлюзу мають однаковий ресурс батареї та можливості обладнання. Однак, такий підхід з “плоскою” архітектурою невідворотно призводить до ускладнень у контексті множинного доступу, маршрутизації, збереження енергії вузлів та управління мережею. Мобільність стоків може розглядатися як прояв гетерогенності, що дозволяє реалізувати мережеву ієрархію та кластеризацію, які можуть бути використанні для покращення масштабованості мережі та часу іï функціонування.

На перший погляд, підвищення швидкості вузла v має підвищувати ефективність системи, оскільки за рівний проміжок часу стік може встановити контакт з більшою кількістю вузлів та зібрати більше інформації з сенсорів. Проте, ми повинні уважно вибирати цей параметр з огляду на наступні фактори. 3 одного боку, чим більша швидкість стоку, тим вище ймовірність для статичного вузла встановити передачу даних. 3 іншого, якщо мобільний стік рухається через ефективну зону зв'язку з сенсором занадто швидко, існує висока ймовірність що тривалість контакту буде недостатньою для передачі потенційно довгого пакету. Іншими словами, при збільшенні швидкості стоку зростає ймовірність втрат переданих пакетів. Таким чином вибір швидкості мобільного стоку перетворюється в компроміс між мінімізацією затримки передачі даних від сенсорів та мінімізації ймовірності втрат переданих пакетів.

\section{1 Затримка зустрічі між сенсором та вузлом}

Нехай мережа складається 3 m мобільних стоків та $\mathrm{n}$ статичних сенсорів у колі одиничного радіусу. Стік та сенсор мають однаковий радіус передачі r. Шаблон переміщення мобільного стоку $M_{i}(i=1, \ldots \mathrm{m})$ відповідає моделі переміщення $з$ випадковими напрямками, проте, з постійною швидкістю v. Траєкторія стоку визначається послідовністю епох. Протягом кожної епохи швидкість руху v для $M_{i}$ та напрямок руху є сталим та не залежать від позиції стоку. Визначимо $Q_{\mathrm{i}}$ як тривалість епохи для $M_{i}$, яка визначається як часовий інтервал між початковою та кінцевою точками $M_{i} \cdot Q_{i}$ - випадкова величина з експоненційним розподілом. Розподіл різних $Q_{i}(i=1, \ldots, m)$ незалежний та однаково розподілений випадкові величини з рівним середнім значенням $\bar{Q}$. Відповідно тривалість епохи для різних $L_{i}$ також випадкові величини з рівним середнім значенням $\bar{L}=\bar{Q} v$.

Припустимо, що розподіл мобільних стоків стаціонарний. Іншими словами, ймовірність підходу незалежних мобільних стоків до певного статичного вузла 3 
різних боків однакова. Визначимо, що факт зустрічі статичного сенсора $N_{j}(j=1, \ldots, n)$ та одного мобільного стоку $M_{i}$, відповідає ситуації, коли $M_{i}$ покриває $N_{j}$ протягом епохи. Оскільки $M_{i}$ покриває площу $\pi r^{2}+2 r L_{i, k}$ протягом $k-і ̈$ епохи, тоді кількість епох $X_{i}$, яка необхідна для першої зустрічі сенсора та стоку геометрично розподілена величина [6] з функцією розподілу:

$$
F_{x_{i}}(x)=\sum_{x_{k} \leq x} p(1-p)^{k-1}
$$

У випадку кількості мобільних стоків більш ніж 1 затримка зустрічі сенсора та стоку розраховується як затримка до моменту, коли перший мобільний стік встановив контакт з вузлом. Таким чином, кількість епох, що необхідна для зустрічі, складає мінімумом для усіх $X_{i}(i=1, \ldots, m)$ з функцією розподілу:

$$
F_{x}(x)=1-\left[1-F_{x_{i}}(x)\right]^{m} \cong \sum_{x_{k} \leq x} m p(1-p)^{k-1}
$$

Взявши $\bar{X}$ як середнє значення для $X$, очікувана затримка зустрічі вузла та стоку:

$$
\overline{D_{1}}=\bar{X} \cdot \frac{\bar{L}}{\mathrm{v}}
$$

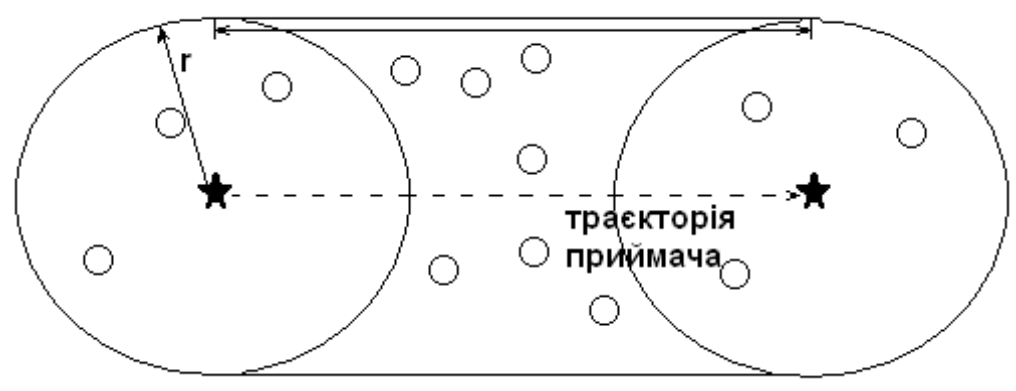

Рис. 4. - Ілюстрація до розрахунку функції розподілу затримки зустрічі сенсора та стоку

Ці результати дають певне уявлення про спосіб вибору параметрів для мінімізації затримки зустрічі сенсора та стоку. Якщо збільшити радіус радіопередачі r, або збільшити число мобільних стоків m або швидкість стоку v, затримка може бути зменшена. Проте, наведений аналіз не враховує час, що необхідний для передачі даних при кожній зустрічі стоку та сенсора. Якщо довжина повідомлення не $\epsilon$ відносно малою, повідомлення може бути розділене на декілька сегментів і надіслане в декілька стоків.

\section{2 Затримка доставки великих повідомлень}

У випадку сегментації пакетів, розбиті пакети можуть бути надіслані до різних мобільних стоків, а потім об'єднані в необхідному порядку. Затримка доставки повідомлень визначається здебільшого тривалістю передачі пакетів. Оцінка часу відновлення порядку пакетів не входить у завдання цієї роботи. 
Припустимо, що кожен сенсор може знаходитись у одному з двох станів: активний та сон, тривалість яких має експоненційний розподіл з середнім значеннями $1 / \lambda$. Таким чином, надходження повідомлень - це пуасонівський процес $з$ середнім значенням інтенсивності $\lambda$. Для повідомлень 3 постійною довжиною L, постійною пропускною здатністю каналу w, число часових слотів, необхідне для передачі повідомлення складає $\mathrm{T}=\mathrm{L} / \mathrm{w}$. Тоді, при ймовірності надання послуги $\rho=m \pi r^{2}$, час обслуговування повідомлення - випадкова величина підпорядкована розподілу Паскаля (лема 1 [7]). Таким чином, ймовірність того, що повідомлення буде надіслано протягом не більше ніж х часових слотів:

$$
F_{x}(x)=\sum_{i=0}^{x-T}\left(\begin{array}{l}
T+i-1 \\
T-1
\end{array}\right) p^{T}(1-p)^{i}
$$

Такий розподіл Паскаля має середнє значення:

$$
T / p=L / \pi m w r^{2}
$$

При середній пуасонівській інтенсивності повідомлень $\lambda$ та для часу обслуговування за розподілом Паскаля

$$
\mu=p / T=\pi m w r^{2} / L
$$

процес генерації даних та їх передачі може бути змодельовано чергою $M / G / 1$. Таким чином, середнє значення затримки доставки повідомлень може бути виражено як:

$$
\overline{D_{2}}=\frac{1}{\lambda}\left[\rho+\frac{\rho^{2}+\lambda^{2} \rho^{2}}{2(1-\rho)}\right]
$$

де $\rho=\lambda / \mu$. Для спрощення ми нехтуємо впливом інтенсивності надходження повідомлень і обираємо $\lambda=1$, тоді:

$$
\overline{D_{2}}=\frac{1}{\mu-1}=\frac{1}{\frac{\pi m w r^{2}}{L}-1}
$$

Приведені залежності показують, що зменшення довжини повідомлення $L$ або збільшення радіусу передачі $r$ і кількості мобільних стоків т дозволяє зменшити затримку доставки повідомлень.

\section{Висновок}

Мета мобільних безпроводових сенсорних систем (МБСМ) - реалізація масштабного збору інформації через безпроводові мережі та мобільні пристрої збору інформації (стоки). Теоретичний аналіз показав, що при наявності відомостей про особливості руху мобільних стоків, мультискачкова схема кластеризації 
може забезпечити доставку пакетів від сенсора до стоку за обмежений час та 3 достатньою енергетичною ефективністю. Послаблення обмежень граничного часу доставки пакетів дозволяє далі підвищувати економію енергетичних ресурсів. Було визначено, що мобільність стоків може знизити рівень споживання енергії i, таким чином, продовжити час функціонування мережі. 3 іншого боку, негативним ефектом у такому разі є ріст затримки доставки повідомлень та ймовірність втрати повідомлення. Аналогічні проблеми виникають при виборі щільності розміщення мобільних стоків (кількість стоків та радіус їх дії).

Також у роботі була представлена мультирівнева архітектура для мобільних безпроводових сенсорних мереж як ключовий гравець парадигми повсюдних обчислень майбутнього. Після опису архітектурного рішення приведено аналіз впливу мобільності на показники продуктивності роботи БСМ. Ієрархічна багаторівнева модель повинна забезпечити високу продуктивність роботи та достатню масштабованість для мереж великого розміру.

\section{Список використаних джерел}

1. Прищепа Т.О. Порівняльний аналіз форматів передачі інформації у безпроводових сенсорних системах на безпомилковість / Науковий вісник АМУ, серія "Техніка" в. 8, c. $122-127,2014$

2. Толстикова Е.В. Минимизация избыточности объема передачи данных в сети радиодатчиков // Проблеми інформатизації та управління. - 2010. - №1(29). C. $168-171$.

3. О. І. Лисенко, Т. О. Прищепа Алгоритм пошуку доцільного розташування вузлів безпроводових сенсорних мереж / Збірник матеріалів Міжнародної науковотехнічної конференції «Проблеми телекомунікацій - 17», 2017.

4. Валуйський С. В., Прищепа Т. О., Димид М. Д. Алгоритм пошуку раціонального розміщення ретрансляторів при розгортанні безпровідних сенсорних мереж / Науковий вісник Академії муніципального управління. Збірник наукових праць. Серія «Техніка». - 2016. - Вип.11. - С.1-9.

5. Canfeng Chen, Jian Ma, MEMOSEN: Multi-radio enabled Mobile Wireless Sensor Network / In Proc. of AINA 2006

6. Liu, B., Brass, P., Dousse, O., Nain, P., Towsley, D. Mobility Improve Coverage of Sensor Networks / Proceedings of ACM MobiHoc 2005

7. Y. Wang and H. Wu, DFT-MSN: The Delay Fault Tolerant Mobile Sensor Network for Pervasive Information Gathering / Proc. of IEEE INFOCOM_06, Barcelona, Spain, 2006 (April 23-29) 